black is partly obscured by yellow pollen, segments 2,3 and 4 each with one cross-band of moderate width, situated somewhat nearer the base of the segment, the band on segment 2 is interrupted at the middle, and does not reach the margin, while the others are entire, and attain the lateral margin. The extreme posterior margin of segment 2 is shining, and also the lateral margins, leaving an $\mathrm{H}$-shaped velvely-black area; segments 3 and 4 are velvety-black in front of the cross-band and shining behind it. Hypopygium shining black. Venter with yellow cross-bands on segments 2 and 3 . Femora black except narrowly at the knees; tibir yellow, with a dark spot on distal half; the front and middle tarsi have the basal joints yellow and the distal joints dark, the posterior tarsi are dusky, with the distal joints darker. Halteres yellow. Wings brownish, especially toward the costal border.

Length, $\mathrm{r} 3 \mathrm{~mm}$. (nasica $=$ referring to the nose).

Described from a single specimen taken in the Hope Mts., July 27 , I 906 , by Mr. R. S. Sherman.

To include the new species of Sphecomyia, I have amended Williston's table (Synopsis N. A. Syrphide, p. 25\%) as follows:

I. Aıtennæ very long, third joint short............... vittata.

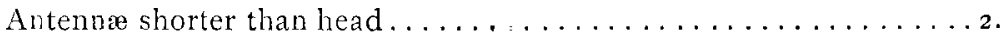

2. Scutellum yellow at base; a complete black facial stripe from antennæ

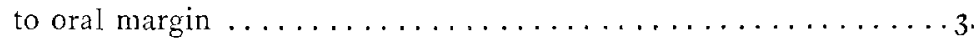

Scutellum entirely black; facial siripe wanting in male (there is in the female of occidentalis a stripe which is attenuated at both ends) . . 4 .

3. Yellow cross-bands of abdomen very broad .......... brevicornis.

Cross-bands narrow . . . . . . . . . . . . . . . . . .

4. Abdominal segments 2 to 4 each with two yellow

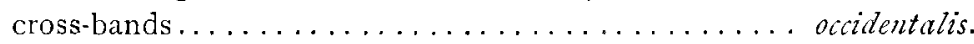

Abdominal segments with only one yellow cross band....... nasica.

\title{
ARGYNNIS ASTARTE, DOUBL.-HEW.
}

BY HENRY SKINNER, M.D., PHILADELPHIA.

This was the butterfly we did not get. Dr. James Fletcher and the writer arrived at Lake Louise, in the Rocky Mountains of Alberta, on the second day of August. One of the insects we were most anxious to obtain was Argynnis astarte, described in 1848 , and not rediscovered until r888. Dr. Fletcher said Mr. Bean had taken the species on the 
very summit of Mt. St. Piran, so we made the ascent of that peak. When we arrived at the rocky top, the temperature was below freezing and snow was falling and the wind blowing a fearful gale. Dr. Fletcher captured a specimen of Chionobas Beanii at a time when the sun shone through a break in the clouds. A butterfly came toward me as though it had started from the South Pole, and when I raised my net to make a stroke it turned and made for the North Pole, and, as far as I know, never stopped until it reached there. I feel sure it was astarte. The weather continued bad during our brief stay in the mountains, and we did not get this interesting species. It is said in a general way that the species is found about the tops of the Rocky Mountains of Canada, and this article is a contribution towards our knowledge of its habitat. It is quite interesting, and perhaps important, to know the exact places where species are found. Mr. Bean says it occurs on a mountain, three miles south-west of Laggan, 8,500 ft. altitude, and on a low smooth mountain directly north of Laggan. He also says it occurred at Lake Agnes in 1892 .

Mrs. Nicholl says: "Everywhere Brenthis astarte was to be seen, though not generally to be caught, on every peak over $8,000 \mathrm{ft} . "$ The males haunt the summits, and the females are to be found on the highest grassy slopes. Mrs. Nicholl records it from Glacier Crest, Selkirk Mountains. Mrs. Chas. Schæffer recently presented two specimens to the Academy of Natural Sciences of Philadelphia, which were taken on Mt. Athabasca $(7,200 \mathrm{ft}$. alt.?). She says it has also been taken on Mt. Temple, above the saddle. Mr. Wolley Dod records it from Devil's Lake, near Banff. Mr. N. Sanson captured a specimen on Sulphur Mountain at Banff. From the above records, where should a collector go to get the species? It is no joke to climb these mountains, and one cannot step from the top of one to the top of another on the basis that they are flying around nearly all the peaks over $8,000 \mathrm{ft}$. altitude. Some of the localities mentioned are exact and some are not. It would be far better to give the names of the peaks where any butterfly is found, and if possible the altitude of the place of capture. Mr. Bean gives a very interesting account of the altitudes where he worked, but does not name the peaks. Perhaps they were not named when he was at Laggan.* I wish to pay tribute to the valuable work done by Mr. Bean in making known the butterfly fauna of this region.

* This was actually the case with most of the mountains at Laggan in I890, when Mr. Bean rediscovered $A$. astarte.-[ED. C. E. 